\title{
Editorial
}

\section{Em defesa da publicação científica}

I Kenneth R. de Camargo Jr. I

Universidade do Estado do Rio de Janeiro, Instituto de Medicina Social, Rio de Janeiro, RJ, Brasil

A questão da múltipla autoria nas publicações científicas voltou a ser objeto de discussão (WOOLSTON, 2015) após a publicação de um artigo sobre o genoma da drosófila (LEUNG et al., 2015) contendo mais de mil autores. E esse número, ainda que inesperado no campo biomédico, está longe de qualquer recorde; apenas a título de exemplo, o artigo contendo a evidência empírica da existência do bóson de Higgs (AAD et al., 2012) teve um total de 2.932 autores. Embora a tendência de crescimento do número de autores por artigos seja um fenômeno já observado (CAMARGO JR; COELI, 2012), e existam situações em que um número incomumente grande de pesquisadores tenha de fato contribuído significativamente para a elaboração do artigo, há um momento em que inevitavelmente se coloca em questão o próprio significado da autoria.

Não foi por outra razão que o International Committee of Medical Journal Editors (ICMJE) se preocupou, já em 1988, em criar um referencial para a atribuição de autoria a um artigo (ICMJE, 1988). Nós, da Physis, já vínhamos adotando medidas rigorosas para prevenir a proliferação espontânea de autores; passamos, adicionalmente ao que já vínhamos fazendo, a limitar em quatro o número máximo de autores; artigos que ultrapassem esse limite deverão ter justificativa extraordinária, e continuamos nos reservando o direito de avaliar a contribuição efetiva de cada nome apresentado como autor. Acreditamos que esse zelo é também parte da tarefa editorial, e um elemento importante de valorização da própria ideia de autoria.

Em outra discussão ligada à publicação científica, Alaisdar Taylor, no blog sobre publicação da London School of Economics (TAYLOR, 2014), assinalou e criticou o crescimento de uma indústria de relaçôes públicas (RP) ligada a instituições de pesquisa. $\mathrm{Na}$ esteira da retração e decadência do jornalismo 
em geral e particularmente do científico, o noticiário sobre ciência passa a ser simplesmente a reprodução de press releases divulgados por empresas ou escritórios de RP ligados à indústria ou centros de pesquisa, fenômeno que já havia sido apontado (RAMPTON; STAUBER, 2002) e só vem se agravando desde então. A baixa qualidade da informação científica divulgada na imprensa em geral é devida também a essa ação, que exagera resultados de pesquisa e extrapola ou faz inferências que não estão presentes no estudo divulgado. E em boa parte, fora as habituais estratégias de marketing de certas indústrias, no caso de universidades a pressão de processos avaliativos tem papel importante na produção dessa distorção. A necessidade de ver determinadas pesquisas ganharem publicidade e serem citadas pode contribuir (e, segundo o autor citado, efetivamente o faz) para a baixa qualidade da divulgação científica, o que pode ter consequências particularmente danosas quando a pesquisa aborda questôes relativas à saúde.

Esses problemas aparentemente disparatados estão relacionados, ainda que indiretamente, às pressões ubíquas pela publicação, em particular pelos equívocos quantitativistas dos processos de avaliação de pesquisadores e instituições. Essa temática é objeto de mais um novo texto crítico, o manifesto de Leiden (HICKS et al., 2015), divulgado recentemente pela revista Nature. O manifesto propõe dez princípios, alguns repetindo ideias já contidas em documentos anteriores, como o Declaration on Research Assessment (DORA) (CAGAN, 2013), outros originais e particularmente relevantes para as circunstâncias atuais da publicação científica no Brasil - em particular, o terceiro item do seu decálogo de proposiçóes, que tem como título "Proteger a excelência da pesquisa com relevância local". Neste item, os autores enfatizam o equívoco de exigir-se a publicação apenas em língua inglesa, e concluem: "métricas construídas sobre literatura de alta qualidade em outras línguas que não o inglês serviriam para identificar e recompensar a excelência em pesquisas relevantes localmente" (HICKS et al., 2015, p. 430).

Tais pressões sobre a atividade de publicação científica representam ameaças concretas à sua qualidade e legitimidade. $\mathrm{O}$ recém-constituído Fórum de Editores de Revistas de Saúde Coletiva se reunirá durante as atividades pré-congresso do $11^{\circ}$ Congresso de Saúde Coletiva, e esses temas certamente estarão na pauta de discussōes. Nossas publicações são um acervo precioso para a Saúde Coletiva; zelar por elas é também garantir a qualidade da produção científica da área. 


\section{Referências}

AAD, G. et al. Observation of a new particle in the search for the Standard Model Higgs boson with the ATLAS detector at the LHC. Physics Letters B, v. 716, n. 1, p. 1-29, 2012.

CAGAN, R. San Francisco Declaration on Research Assessment. Disease models \& mechanisms, p. dmm. 012955, 2013.

CAMARGO JR, K. R. de; COELI, C. M. Multiple authorship: growth or inflationary bubble? Revista de Saúde Pública. São Paulo, v. 46, n. 5, p. 894-900, 2012.

HICKS, D. et al. Bibliometrics: The Leiden Manifesto for research metrics. Nature, v. 520, n. 7548, p. 429-431, 2015.

INTERNATIONAL COMMITTEE OF MEDICAL JOURNAL EDITORS. Uniform requirements for manuscripts submitted to biomedical journals. British Medical Journal (Clinical research ed.), v. 296, n. 6619, p. 401, 1988.

LEUNG, W. et al. Drosophila Muller F elements maintain a distinct set of genomic properties over 40 million years of evolution. G3: Genes| Genomes| Genetics, v. 5, n. 5, p. 719-740, 2015.

RAMPTON, S.; STAUBER, J. Trust us, we're experts: how industry manipulates science and gambles with your future. New York: Penguin, 2002.

TAYLOR, A. The growth of the science PR industry has resulted in an overly exaggerated presentation of research findings. Impact of Social Sciences. Retrieved May 28, 2015, from http://blogs.lse.ac.uk/impactofsocialsciences/2014/06/03/the-perils-of-the-press-release/, 2014, June 3.

WOOLSTON, C. Fruit-fly paper has 1,000 authors. Nature, v. 521, n. 7552, p. 263-263, 2015. 